\title{
Credit Risk Management and Entrepreneurship Development in Nigeria: A Case Study of Small and Medium Scale Industries in Ondo State
}

\author{
Ogunyemi Joseph Kayode \\ Department of Banking and Finance \\ Adekunle Ajasin University \\ P.M.B 00I, Akungba Akoko, Ondo State, Nigeria \\ Email: jossykay2013@gmail.com \\ Mufutau Akanmu Popoola \\ Department of Business Administration \\ Kwara State University \\ P.M.B I530, Malete, Nigeria \\ Email:mufupop@yahoo.com \\ Adewole Joseph Adeyinka \\ Department of Banking and Finance \\ Adekunle Ajasin University \\ P.M.B 00I, Akungba Akoko, Ondo State, Nigeria \\ Email: princeadeyinkaadewolej@gmail.com
}

\begin{abstract}
The paper summarizes the arguments and counterarguments within the scientific discussion on credit risk management and entrepreneurship development in Nigeria with focus on small and medium scale industries in Ondo State. The objective of the study is to examine the effect of credit risk management on entrepreneurship development. The study adopted the use of descriptive statistics and regression analysis method to test the hypothesis formulated. The results indicated that entrepreneurship development is being hampered by ineffective credit risk management. The findings has shown that Small Scale Enterprise still suffers greatly from inadequate policy on fund raising, lack of risk management personnel, lack of credit advisory unit in loan houses and Inability to determine appropriate source of funding which significantly affects their level of development. The findings of this study have also found out that the Nigerian markets are filled with numerous business opportunities. Based on the findings, it was recommended that increased government support, uninterrupted power supply and communication link, provision of skilled manpower and computer wizard in operation of payment system, collaboration among banks, provision of adequate security and fight against corruption would assists and improve the growth and development of entrepreneurship in Nigeria.
\end{abstract}

\section{Keywords: MSMEs, Performance, Local Government Support, Urban Centers, Wolaita.}

\section{Introduction}

Every purposeful and responsible government quest to improve the living standard of its people on a continual basis (Azende, 20II).According to Kpelai (2009) asserts that SMEs are the engine room for the growth of any developing economy, because they form the bulk of business activities in developed and developing economies like Nigeria. Many economies like Canada, Croatia, etc have acknowledged that SMEs are crucial for industrial restructuring and have formulated national SME financing policies, targeted at developing the sub-sector. However, the small business' contribution to macro- economic development is inhibited by the fact that they have no, or only overpriced, access to finance institutions and other services (Schneider-Barthold, 2002).

Credit risk management is a structured approach to managing uncertainties through risk assessment, developing strategies to manage it, and mitigation of risk using managerial resources. The strategies include transferring to another party, avoiding the risk, reducing the negative effects of the risk, and accepting some or all of the consequences of a particular risk. According to Plourd (2009), the importance of risk management is now escalated above issues such as long-term and short-term financing constrains. Proclaiming the existence of a risk management strategy is insufficient, enterprises need to actively engage 
in risk management practices to address the convergence of major risks as experienced in the current economic climate where the credit crisis risk, fluctuating commodity prices, increased government debt, rising unemployment and declining consumer spending are impacting individually and combined, on enterprises.

Entrepreneurship development involves leadership skill, managerial quality, transparence and accountability which have created opportunities for industrial development, communities and individual empowerment. A number of studies have been carried out on the effect of Microfinance on Entrepreneurial Development. In fact, academic interest that shows the effect of entrepreneurial development evidenced by the fact that some academic journals have devoted special issues to research establishing this linkage. However, credit risk arises whenever a lender is exposed to loss from a borrower, counterparty, or an obligatory who fails to honour their debt obligation as they have contracted (Luy, 2010). According to Colquitt (2007), this loss may derive from deterioration in the counterparty's credit quality, which consequently leads to a loss to the value of the debt, or according to Crouhy,M.; Galai, D. \& Mark (2006), the borrower defaults when he is willingly to fulfil the obligations. Funding has therefore remained one of the key managerial problems that keep confronting business enterprises in Nigeria today which may due to improper credit risk management. Therefore, this study will examine credit risk management and entrepreneurship development in Nigeria as it relates to small scale industries in Ondo State.

The problem of SME financing has received the most tremendous research efforts from researchers. Some notable works in this respect include Inang \& Ukpong (2002) \& Aruwa (2004). In their findings, four problems in financing SMEs have become recurrent: the cost of capital; risk; the inappropriate terms on bank loans; and the shortage of equity capital. Over the years government has enacted various policies and introduced schemes aimed at financing SMEs (Amaeshi 2007). However it is worrisome to note that SMEs are starved of funds and the financing problems keeps reoccurring (Mambula, 2002).

Credit risk management has become a global issue in area of small scale industrial sector, deficiency in entrepreneurship development create a lot of constraint to economic development especially developing countries.

The SMEs in Nigeria are still characterized by numerous key setbacks among which is the extremely high cost of administration of small loans, this is worsened by high interest rates; discriminations from banks averse to risk of lending to small borrowers (Onugu, 2005). All these, have affected the SME in delivering the expected results and various skeptics have been raised against the increasing recognition of SMEs in the research literature in both developed and developing countries in recent time.

Credit risk management practices is an issue of concern in financial institutions today and there is need to develop improved processes and systems to deliver better visibility into future performance. There have been controversies among researchers on the effect of credit management techniques adopted by various institutions. According to Saunders and Allen (2002), good selection strategy for risk monitoring is adopted by the credit unions implies good pricing of the products in line with the estimated risk which greatly affect their profitability. Mwirigi (2006) on the other hand stated that loan portfolio management and operational efficiency management are the most important to consider in Credit Risk Management as they are the most important in enhancing the performance. The principal concern of this study is to ascertain the effect of various credit risk management techniques and strategies that are adapted by entrepreneurial on their performance.

From this background, it is therefore imperative to examine credit risk management and entrepreneurship development in Nigeria; a study of small scale industries in Ondo State

The questions that guide the study are (i) what is the effect of credit risk management on entrepreneurship development in Ondo State? (ii) What is the relationship between level of access credit facilities and business expansion among SMEs in Ondo State? (iii) What are the effects of the constraints faced in accessing finance on entrepreneurship development? The broad objective of this study is to examine credit risk management and entrepreneurship development in Nigeria with a focus on small scale industries in Ondo State. The specific objectives are to examine the effect of credit risk management on entrepreneurship development in Ondo State, investigate the impact of access to credit facilities and business expansion among SMEs in Ondo State, identify the effect of the major constraint of access to finance on entrepreneurship development.

The hypothesis for this study is in null forms which are (i) Credit risk management has no significant impact on entrepreneurship development in Nigeria (ii) Access to credit facilities does not have any significant impact on business expansion (iii) The constraints faced in accessing finance does not have any significant effect on entrepreneurship development. Since it has been accepted that development of small scale industry is inevitable in economic development of the country, this study will be of significant benefit to entrepreneurs by helping them to take credit risk management seriously so as not face financial problems or performance problems which can threaten the continuous existence of their business and at the end also affect the economy as a whole. This study will also benefit government to make policy that will improve entrepreneurship development in Nigeria and credit risk management in the country especially for small scale industries.

The study will be of benefit to academia by contributing and broadening existing knowledge of entrepreneurship by student which will in turn help in influencing student's decision for those who might want to venture into entrepreneurship later in life and also to help make sound business decisions. This study focused on some of selected enterprise in Akure, Ondo State whose activities are mainly fall into small and medium scales industries. The small scales enterprises are computer centers and café, rental services, pure water production, sale of phone and phone accessories, fabric distribution, building material sellers, 
telecommunication materials distributors, bookshop/stationary distributor, printing press, and hair cut/dressings e.t.c. However, in order to achieve the objectives outlined in this study, the self-structured questionnaire was employed. The choice of these enterprises arises based on their nature and level of operation as well as the size of the firm because they are mainly subjected to entrepreneurial issues.

\section{Literature Review \\ 2.I Concept of Risk}

Risk is one of the recurrent problems that make SMEs unattractive to investors. Risks are defined as the chance of something happening that will impact upon objectives (Aernorld, 1998). Risk is a part of everyday life. There are many types of risk that will be encountered in business. Some are controllable while others are not. Some are foreseeable while some are unforeseeable. Some have minimal impact on the business while some threaten the longevity of a business. SMEs are businesses in the private sector and they cut across all industries. The nature of risk therefore varies according to the industry in question. The onus is therefore on the owner to identify the risk prevalent in his business and make efforts to embark on good management techniques. Risk management is an integral part of good business governance. It is simply protecting the business from possible negative occurrences, as well as recognizing opportunities and capitalizing on them when they arise (Aruwa, 2004). Risk management is the way in which adverse effects from risk are managed and potential opportunities are realized (Vaughan, 1997).

Giving the vital role played by SMEs in the economic development of any nation, the sector has wide range of expectation by its stakeholders; for example, government expect SMEs to survive, grow and be productive to stabilize the economy, customers expect that the products offered by SMEs should be there for them whenever they need them, big industries that use the products of SMEs are counting on them for their production, investors expect SMEs to operate profitably to enhance the security of their funds. The issue of risk and its management is therefore appropriate for SMEs for the overall interest of the stakeholders and the economy as a whole (Chidi \& Shadare, 20II).

A well-functioning financial system is a key enabler of economic growth. SMEs are an important part of Nigeria's economic growth and development and bank lending is the primary source of external finance for SMEs. Therefore, it is important that the banking sector responds efficiently and effectively to the needs of SMEs. According to Ohanga (2005), there are a number of features of lending generally which potentially could affect the efficiency of the market for lending. Information Asymmetry is a situation where business owners or managers know more about the prospects for, and risks facing their business than do lenders. The implication of raising interest rates and/or curtailing lending is that firms will not be able to finance as many projects as otherwise would have been the case. Information asymmetry is more acute in case of SMEs because their relative size makes them economically unattractive to banks since they are unable to accurately gauge the level of risk involved in lending to SMEs (Ohanga, 2005).

However, due to Lack of easy access to funding/credits, which can be traceable to the reluctance of banks to extend credit to them owing, among others, to poor and inadequate documentation of business proposals, lack of appropriate and adequate collateral, high cost of administration and management of small loans as well as high interest rates (Fabunmi 2004).

\subsection{Sources of Financing SMEs in Nigeria}

The importance of finance to business organisation cannot be over-emphasised. Business finance is however, not easy to come by especially in respect of SMEs. Yet they require funds from every source available to meet their asset needs, working capital needs, and for expansion. According to Ekpenyong and Nyong (1992), there is wide consensus in Nigeria that government policies are skewed in favour of the formal sector to the detriment of the informal sector. This skewness is to the great disadvantage of SMEs in Nigeria since they are more disposed to the funds of the informal sector. The commercial banks, merchant banks, and development banks provide the formal sources of finance to SMEs. The financial system in Nigeria is not in short supply of liquidity, but banks have been very reluctant to grant loans to SMEs, which they regard as a high-risk sector. Most of the banks would rather pay the penalty imposed for not meeting the minimum exposure to preferred sectors of the economy than actually run the risk of being exposed to them. According to Ojo (I984), the sources of investment finance for SMEs include owner's savings and assistance from banks, government institutions, local authorities, co-operative societies, relatives and friends, and money-lenders. The study shows that almost all the funds came from personal savings (96.4\%) with about 3\% from the informal sector and $0.21 \%$ from the formal financial institutions. This trend is further established by a $1983 / 84$ study by the Nigerian institute for Social and Economic Research (NISER). NISER findings show that about $73 \%$ respondents raised their funds from personal savings, while only about $2 \%$ obtained their funds from the formal financial institutions.

\subsection{Small and Medium Industries Equity Investment Scheme (SMIEIS) Fund}

In Nigeria, the formal financial institutions have been organized to finance SMEs through venture capital financing in the form of a SMIEIS fund. This was in response to the Federal government's desire to promote SMEs as vehicles for rapid industrialization, sustainable economic development, poverty alleviation and employment generation. Venture capital financing supplements or takes the place of credit facilities that the conventional banks are unwilling to give. The provider of the funds 
may initially part with the funds as a loan, but specifically with the idea of converting the debt capital into equity at some future period in the enterprise. The return from such investment should be high to compensate for the high risk. Venture capital may be regarded as an equity investment where investors expect significant capital gains in return for accepting the risk that they may lose all their equity (Golis, 1998).

The Nigerian government's version of venture capital financing of SMEs -SMIEIS, requires all licensed banks in Nigeria to set aside 10\% of their pre-tax profit for equity investment and to promotion of small and medium-scale enterprises. The goal is to reduce interest rate burden and other financial service charges imposed under normal bank lending. According to Sanusi (2004), a breakdown of the SMIEIS fund investment by sectoral distribution shows that $68.82 \%$ went to the real sector while service related investment ac-counted for 31.I8\%. This, he noted, is a sharp reversal from the initial trend recorded under the scheme. The Bankers Committee has allocated the investment of banks with respect to the fund as $60 \%, 30 \%$, and $10 \%$ of their fund in core/real sector, service-related and micro-enterprises respectively. Analysing the geographical spread of the SMIEIS fund, Sanusi (2004) reported that Lagos-based in-vestments have gulped 56.63\% of the fund, and Abuja and I8 states received the balance $43.47 \%$. The point is about the model of growth of SMEs and financing options available with respect to corporate governance.

Golis (1998), submit that venture capitalists do not seek enterprises on the start-up and survival stage but only in the stability and rapid growth stages did the venture capitalists appear which goes to show their fear because of the risk associated with the early stages. Yet the method of financing remains a critical success factor for SMEs. To be eligible for equity funding under the scheme, a prospective beneficiary shall:

i). Register as a limited liability company with the Corporate Affairs Commission and comply with all relevant regulations of the Companies and Allied Matters Act (1990) such as filling of annual returns, including audited financial statements;

ii).Comply with all applicable tax laws and regulations and render regular re-turns to the appropriate authorities (Bankers Committee Revised, 2005).

Aruwa (2005) laments that, given the developmental stage of Nigeria's dominant SMEs; it is difficult for them to meet any of these requirements. Consequently, SMEs in Nigeria do not have the capacity to access funds from SMEEIS.

\subsection{Concept of Entrepreneurship}

The concept of entrepreneurship as an organized knowledge came into being about hundred years ago. Though, the economists from Adam Smith to Marshall were talking about it but without assigning the name of entrepreneurship. They used the terms as employer, the master, the merchant and the undertaker for carrying out different entrepreneurial activities now comprising of entrepreneurship. It was Pantillon, who first brought out the term entrepreneur (Murthy 1989) and entrepreneurship was recognized in economic literature.

Somoye (2013), defines entrepreneurship and the entrepreneur as "An act of possessing an inclination for selfdevelopment, ability to innovate, nurtures an enterprise and having means of and access to finance in both formal and informal financial sub-sectors to achieve a successful investment towards sustainable economic growth”.

Entrepreneurship is a human activity which plays a major role in economic development its history is as old as human history it indicates to the spirit of enterprise. Such a spirit transforms the man "from a nomad to a cattle rearer, to a settled agriculturist, to a trader and an industrialist" (Murthy 1989). An entrepreneur is a person while entrepreneurship is the process of its actual working. Entrepreneurship is also consistently equated with the establishment and management of small business enterprises. In United States, the entrepreneur is often defined as one who starts his own, new and small business. (Drucker 1985).

Modern literature on economic development classifies the entrepreneurship in four broad categories. The innovating, The imitating, The Fabian and The drone entrepreneurship (Williamson and Bultrick I969).Innovating and imitating entrepreneurship is generally available in developed countries and very rare and limited in developing countries. Developing countries have in them the Fabian and Drone types of entrepreneurship.

The reason of the backwardness of the developing countries lies in the fact that they are deficient in innovating and imitating entrepreneurs whereas they are found in abundance in developed countries. Entrepreneurship has been a major factor in the economic growth of the west, the USSR and of Japan in Asia and it was undoubtedly of innovating and imitating type which made the process of development smooth and fast there. This bring to mine an area of interest that has captured the imagination of scholars regarding the phenomenon of entrepreneurship is the big question, "Are entrepreneurs born or made". Many people believe that entrepreneurs possess innatic, genetic talents. However, experts generally agree that most entrepreneurs were not born, rather, it is the environment, traning family tradition etc which help in the development of successful entrepreneurs (Jha,(I989).

The role played by entrepreneurship in the development of western countries has made the people of developing countries very much conscious of its importance in the programme of rapid economic development. People have begun to realize that for achieving the goal of development it is necessary to increase both the quantitative and qualitative entrepreneurship in the country. The qualitative entrepreneurship implies the stress on innovating and the quantitative implies the stress on imitating 
entrepreneurship. Both of them contribute stimulus for development. It is also known that even though a country has resources labour, technology, capital and raw material etc., but these remain under-explored in the absence of the active and enthusiastic entrepreneurs, who have the ability to organize the various factors of productions.

Innovating entrepreneurs are rarely found in developing countries. In the past these countries have depended, largely on developed countries for their manufacturing requirements. But now they are planning to develop as early as possible for which they require modern kinds of innovating and imitating entrepreneurs. Fabian entrepreneurs do not want to take huge risk, they do not believe in making big changes, unless, of course, it becomes inevitable for their existence. Drone entrepreneurs go on using their own traditional techniques, even at a loss.

Industrial entrepreneurship in developing countries is about 15\% of world industrial output. See; Woriel Baul Survey, 2002. The efforts are in progress for enlarging the developing countries share of world industrial output from $7 \%$ in 1974 to at least $25 \%$ by the year 2005 A.D. While scope for bilateral and multilateral cooperation exists between developed and developing countries, the developing countries can advantageously establish linkages among themselves in sharing technologies and industrial know how with each other.

In Nigeria, the level of finance for entrepreneurship is one of the lowest in the world (Vision, 2020, 2009). However, while the World Bank (20I0) report indicates that Nigeria's financial system is highly capitalized and vibrant, her contribution to entrepreneurship and MSMEs sector is only about $1.6 \%$ of the total loans and advances to the private sector as of 2009 (CBN, 2009). Nigeria MSMEs are estimated to contribute I0\% of the employment level in Nigeria well below that of the UK 54\%; USA 50.3\%; Bangladesh 80\%; India 80\%; Belgium 66.6\%; South Africa 60\%; Malaysia 57.7\%, Ireland 66.5\% and China 58.8\% (Vision, 2020, 2009).

The Manufacturing (including Micro, Small and Medium Enterprises) sector is acknowledged to have huge potential for employment generation and wealth creation in any economy. Yet in Nigeria, the sector has stagnated and remains relatively small in terms of its contribution to GDP or to gainful employment. Activity mix in the sector is also quite limited-dominated by import dependent processes and factors. Although there is no reliable data, imprecise indicators show that capacity utilization in the sector has improved perceptibly in the period since 1999, but the sector is still faced with a number of constraints with lack of credit availability as the principal constraint. Credit is the largest element of risk in the books of most banks and failures in the management of credit risk, by weakening individual banks and in some cases the banking system as a whole, have contributed, to many episodes of financial instability. A greater understanding of the nature of credit risk, leading to improved measurement and management, would help to strengthen the financial system vis-à-vis the small and medium enterprises in the long-run. An increasing amount of research on credit risk is being carried out within financial firms, central banks, regulators and universities (Iloh, \&Chioke, 2015)

\subsection{Access to Credit Facilities and business expansion}

Access to finance helps all firms to grow, expand and prosper. However, lack of access to credit is a major impediment inhibiting the growth of micro enterprises (GOK, 2005). Furthermore, firms with greater access to capital are more able to exploit growth and investment opportunities (Beck, Demirgüç-Kunt, Laeven, \&Maksimovic, 2006). There is no structured institutional mechanism to facilitate the flow of financial resources from the formal sector through financial institutions to such enterprises. Generally, such enterprises operate on tight budgets, often financed through owner's own contribution, loans from friends and relatives and some bank credit. They are often unable to procure adequate financial resources for the purchase of machinery, equipment and raw materials as well as for meeting day-to-day expenses. This is because, on account of their low goodwill and little fixed investment, they find it difficult to borrow at reasonable interest rates. As a result, they have to depend largely on internal resources. The problem is even acute in rural areas where banks branches are far apart or non-existent (GOK, 2005).

As emphasized by Hatega, (2007), Kauffmann (2005) and the IFC (2006) report "Making finance work for Africa", it is relatively clear that weakly functioning financial markets is the far most important obstacle for SME entry, growth, expansion and investment. Ntakobajira, (2013), in his study found out that access to finance affected performance of SMEs to a great extent because it limited the entrepreneurs' ability to take advantage of opportunity as and when they arose. Nalwelishe (2003) as cited in Ondieki, Nashappi, and Moraa (2013) carried out a research on sources of finance available to small scale enterprises in Nairobi. His objectives were to identify which types of credit are easily obtainable by SSEs and to evaluate the credit policies of SSEs. On access to credit, majority of entrepreneurs relied on limited own and family savings for start-up and additional capital. They hardly rely on external sources of finance. Therefore, these enterprises have poor access to credit. Concerning supply of credit; urban-located enterprises were noted to have achieved a higher success rate than the rural ones.

Interest in access to finance has increased significantly in recent years, as growing evidence suggests that lack of access to credit prevents low-income household and small firms from financing high return investment projects, having an adverse effect on growth and poverty alleviation. They examined literature on the causal relationship between access to financial services and its impact on production. The literature, mostly observation from a few case studies, reveals that access to financial services by the rural people (or low income population segments) can improve their incomes and therefore their welfare (Mutua \&Oyugi, 2005). According to de la Torre et al. (2008) cited in Njeru, Namusonge\&Kihoro, (2012), given the small scale entrepreneurial 
projects and a higher information asymmetry and higher risk, financial institutions find it costly to monitor small businesses, even if advances in technology (including the risk scoring techniques) imply that the banking sector is capable of handling the entrepreneurial finance better than in the past.

\subsection{Credit Risk Management and entrepreneurial development in Nigeria}

In Nigeria one challenge being faced by SMEs is finance due to their risky nature which is caused by their inability to keep proper accounting records, manage the level of risk associated with each source of finance among others.

According to Alfred (20II) good record keeping of financial transactions is one of the key requirements by finance providers to access funds. Unfortunately, this requirement considered very critical for assessing the capacity of Small entrepreneurs to manage funds for sustained growth and expansion is lacking. He further argued that this explains why out of the N40 billion set aside by banks under micro finance scheme for Small-Scale businesses less than 50 percent of the amount has been accessed. Azende (2012) stressed that it is difficult for SMEs to access funds from the formal sources because of stringent collateral security requirement and inadequate risk mitigating schemes for the formal sources of finance. However finance is central to the running of any business and SMEs will be able to attract funds from the formal sector when they are seen not to be risky.

When SMEs do not keep proper record they are considered as being risky. However, SMEs that keep proper accounting records can use the information provided to manage the risk (financial risk) faced by them, because the financial data and ratios form the basis for risk (financial) management. One way of managing risk with financial data is by identifying financial risks through the analyses of the financial statements of the company.

Therefore the results of risks and also weaknesses of the financial situation of the business can be found. The effective keeping of accounts and records by SMEs can be used to assess how their business was and will be able to be economically. More so if the financial analysis is reliable it will help in assessing the insolvency or bankruptcy risk of SMEs and at the same time is easy to apply by SMEs owners. This will aid SMEs managers to effectively manage risk that is within their control through diversification or ignore to undertake such activity and the ones they cannot diversified can be covered or managed through insurance policy.

\subsection{Pecking Order Theory}

Ohanga (2005) asserts that, from the borrower's perspective, if faced with a cost of lending that is above the true risk-adjusted cost, the borrower will have incentives to seek out alternative sources of funding. Bank lending theory suggests that, where information asymmetry and moral hazard are prevalent, firms are likely to fund themselves firstly from retained earnings and then from bank debt rather than issuing equity. This is referred to as the pecking order theory/hypothesis. The theory further suggests that the mix of debt and equity should be the cumulative result of hierarchical financing decisions over time. Evidence around the world indicates that small scale enterprises provide an effective means of stimulating indigenous entrepreneurship, enhancing greater employment opportunities per unit of capital invested and aiding the development of local technology (Sule, 1986: World Bank 1995). Through their wide dispersal, they provide an effective means of mitigating rural-urban migration and resource utilization. Furthermore, by producing intermediate products for use in large scale enterprises, SMEs contribute to the strengthening of industrial linkages. These explain the in-creased interest which developing countries have shown in the promotion SMEs since the I970s (Ekpenyong and Nyong, 1992). Akabueze (2002) asserts that the significance of finance in the drive for economic growth is fairly well established and generally accepted. For instance, the take-off and efficient performance of any industrial enterprises, be it small or large, will require the provision of funds for its capitalization, working capital and rehabilitation needs, as well as for the creation of new investments. Apart from entrepreneurship, funds are required to bring together the other factors of production - land, labour and capital - before production can take place. Provision of funds to the industrial sector, particularly, for the SMEs has, therefore, been of prime interest to policy-makers in both the public and private sectors.

Aladekomo (2003) notes that successive governments in Nigeria have, since the last three decades, shown great interest in financing of SMEs, by establishing specialized banks and other credit agencies/schemes to provide customized funding to the sub-sector to enhance growth and stability. In addition to these, programmes like the Nigerian Directorate of Employment (NDE), Better Life for Rural Women, Family Support Programme, Child Care Trust, People’s Bank, National Poverty Eradication Programme (NAPEP), to mention a few, have been introduced.

The impact of all existing credit schemes to SMEs, in terms of providing funds for meaningful and sustained development among the SMEs, had hardly been noticeable. These credit schemes either have a direct or indirect link with banks. The banks by their nature and position in the economy, therefore, remain the known formal source of finance for enterprises (Agumagu, 2006). It is disheartening to know that a 200I World Bank survey on Nigerian firms showed that although $85 \%$ of the firms had relationships with banks, most of them had no access to their credit. This explains why SMEs in Nigeria represent about $90 \%$ of firms in the Nigerian industrial sector on numerical basis but regrettably contribute as low as one percent to GDP in contrast to countries like Indonesia, Thailand and India where SMEs contribute almost 40\% to GDP (HPACI, 2002). The failure of most of the schemes and the need for a sustainable source of financing SMEs, therefore, necessitated the recent Central 
Bank of Nigeria (CBN) inspired Banker's Committee initiative which is aimed at committing the banking industry to the provision of finance and other ancillary support to the sub-sector via an equity participation scheme.

\subsection{Portfolio Theory}

Since the 1980s, companies have successfully applied modern portfolio theory to market risk. Many companies are now using value at risk models to manage their interest rate and market risk exposures. Unfortunately, however, even though credit risk remains the largest risk facing most companies, the practice of applying modern portfolio theory to credit risk has lagged (Margrabe, 2007). Companies recognize how credit concentrations can adversely impact financial performance. As a result, a number of institutions are actively pursuing quantitative approaches to credit risk measurement. This industry is also making significant progress toward developing tools that measure credit risk in a portfolio context. They are also using credit derivatives to transfer risk efficiently while preserving customer relationships. Portfolio quality ratios and productivity indicators have been adapted. (Kairu 2009). The combination of these developments has vastly accelerated progress in managing credit risk in a portfolio context.

Traditionally, organizations have taken an asset-by-asset approach to credit risk management. While each company's method varies, in general this approach involves periodically evaluating the quality of credit exposures, applying a credit risk rating, and aggregating the results of this analysis to identify a portfolio's expected losses. The foundation of the asset-by-asset approach is a sound credit review and internal credit risk rating system. This system enables management to identify changes in individual credits, or portfolio trends in a timely manner. Based on the changes identified, credit identification, credit review, and credit risk rating system management can make necessary modifications to portfolio strategies or increase the supervision of credits in a timely manner. While the asset-by-asset approach is a critical component to managing credit risk, it does not provide a complete view of portfolio credit risk, where the term risk refers to the possibility that actual losses exceed expected losses. Therefore, to gain greater insight into credit risk, companies increasingly look to complement the asset-by-asset approach with a quantitative portfolio review using a credit model (Mason and Roger, 1998). Companies increasingly attempt to address the inability of the asset-by-asset approach to measure unexpected losses sufficiently by pursuing a portfolio approach. One weakness with the asset-by-asset approach is that it has difficulty identifying and measuring concentration. Concentration risk refers to additional portfolio risk resulting from increased exposure to credit extension, or to a group of correlated creditors (Richardson, 2002).

\section{Methodology}

In this study, survey research design was adopted. Data were collected through primary sources. The primary data were collected through the administration of questionnaires to respondents at the various levels of management during office hours. The population of the study comprised of Small Scale Enterprises in Ondo state. The sample size would be drawn from the population of Small Scale Enterprises in Akure South Local Government of Ondo State. 240 questionnaires were administered and purposive sampling technique was adopted in selecting samples from the population for the purpose of the study. This sampling technique would be adopted so as to ensure that only respondents that are of prior significance and that would readily give needed information in regards to the study were selected. Thus, their responses will be more reliable and used for generalization.

In order to have a comprehensive and reliable source of information for this study primary source of data would be adopted and a structured questionnaire will be designed. The questionnaire would be self-constructed by the researcher and was grouped into three sections; Section A will discuss information on demographic information of participant, section B focuses on the effect of credit risk management on entrepreneurship development while section $C$ focuses on level of accessibility to credit facilities and business expansion among SMEs, using the four point Likert scale for response. Strongly Agree (SA), Agree (A), Disagree (D), and Strongly disagree (SD).

The questionnaire will be designed based on earlier studies conducted to enhance the strength of the research work. The questionnaire would be vetted by the supervisor. A pilot study was also conducted for small group of respondents to validate the questionnaire and to see if expected information was obtained. Data collected would be analysed using statistical tools in order to test the hypothesis, achieve objectives and answer research questions. In order to find answers to research questions, the inferential statistical tool would be adopted and this was achieved using Analysis of Variance (ANOVA) and regressions using SPSS 20.0 statistical packages.

\section{Results}

This section deals with the presentation, analysis and interpretation of data collected and analyzed empirically for the purpose of achieving the stated objectives of the study. 
Figure I:

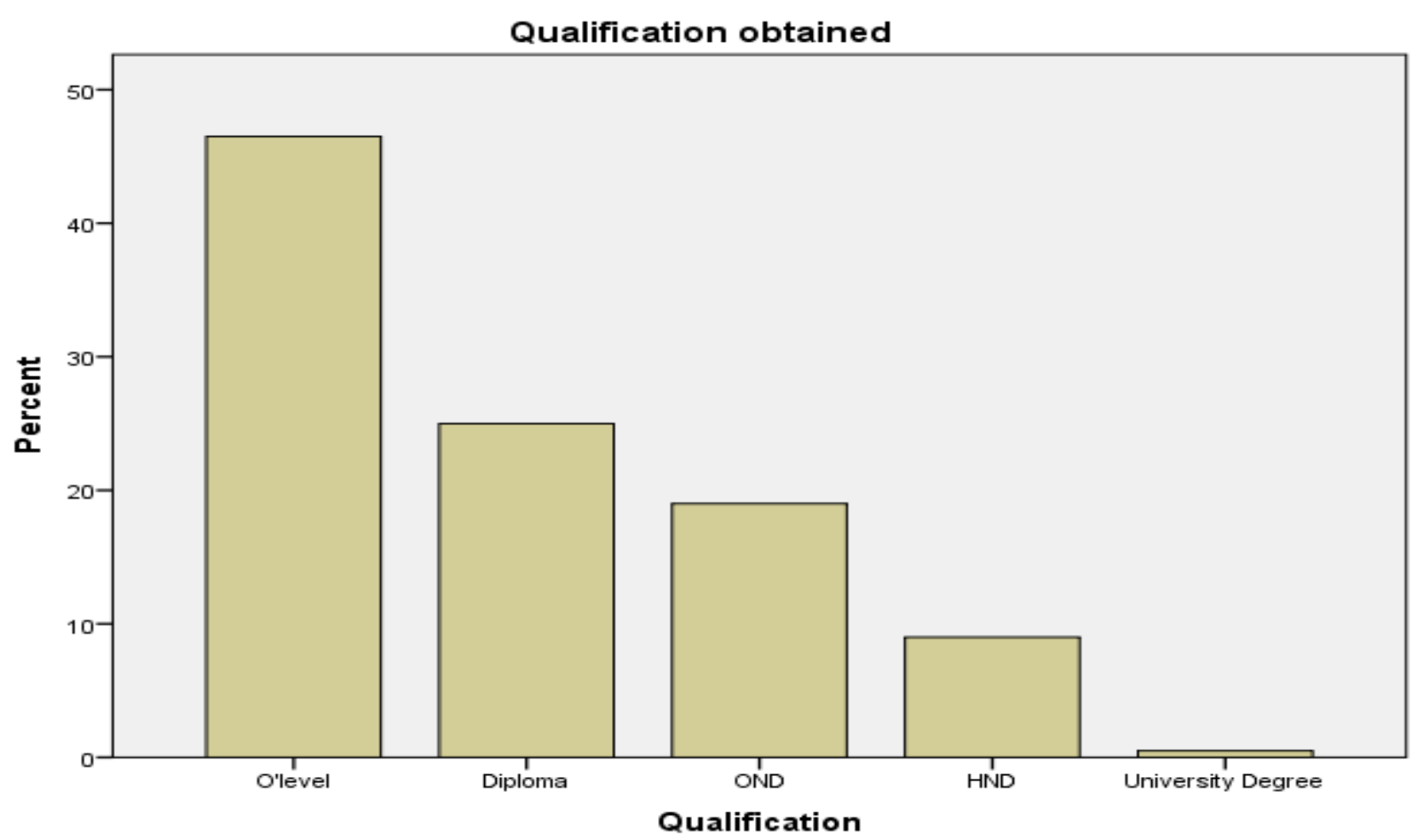

Source: Field Survey (2019).

The chart above revealed that $45.5 \%$ of the respondents were O'level certificate holders, $25.0 \%$ of the respondents are those with Diploma certificate, $19.0 \%$ of the responses are OND certificate holders, $9.0 \%$ of the respondents are HND certificate holders. However, $0.5 \%$ of the responses are B.Sc certificate holders. This statistics therefore form a basis for the high number of informal Small Scale Enterprises in Ondo State.

Figure 2:

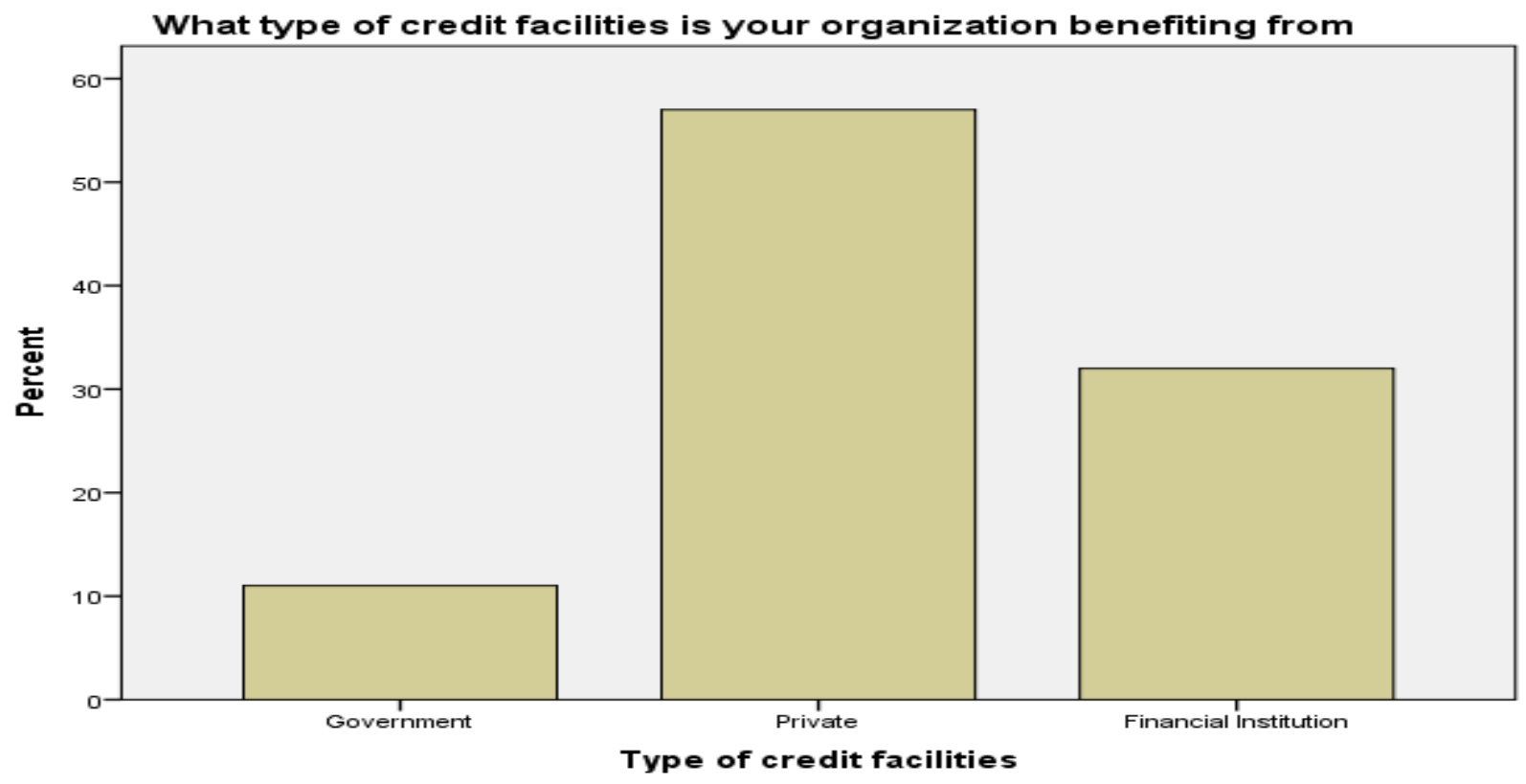

Source: Field Survey (2019). 
The chart above revealed that $12.0 \%$ of the respondents benefit credit facilities obtained in form of grants from Government. $55.0 \%$ of the respondents benefit credit facilities obtained internally or from friends and relatives. However, $38.0 \%$ of the respondents obtain their credit facility from financial institution notably Micro finance banks. This statistics revealed that most of the sources of credit facility obtained by SSE operators are internal source of credit generation.

Figure 3:

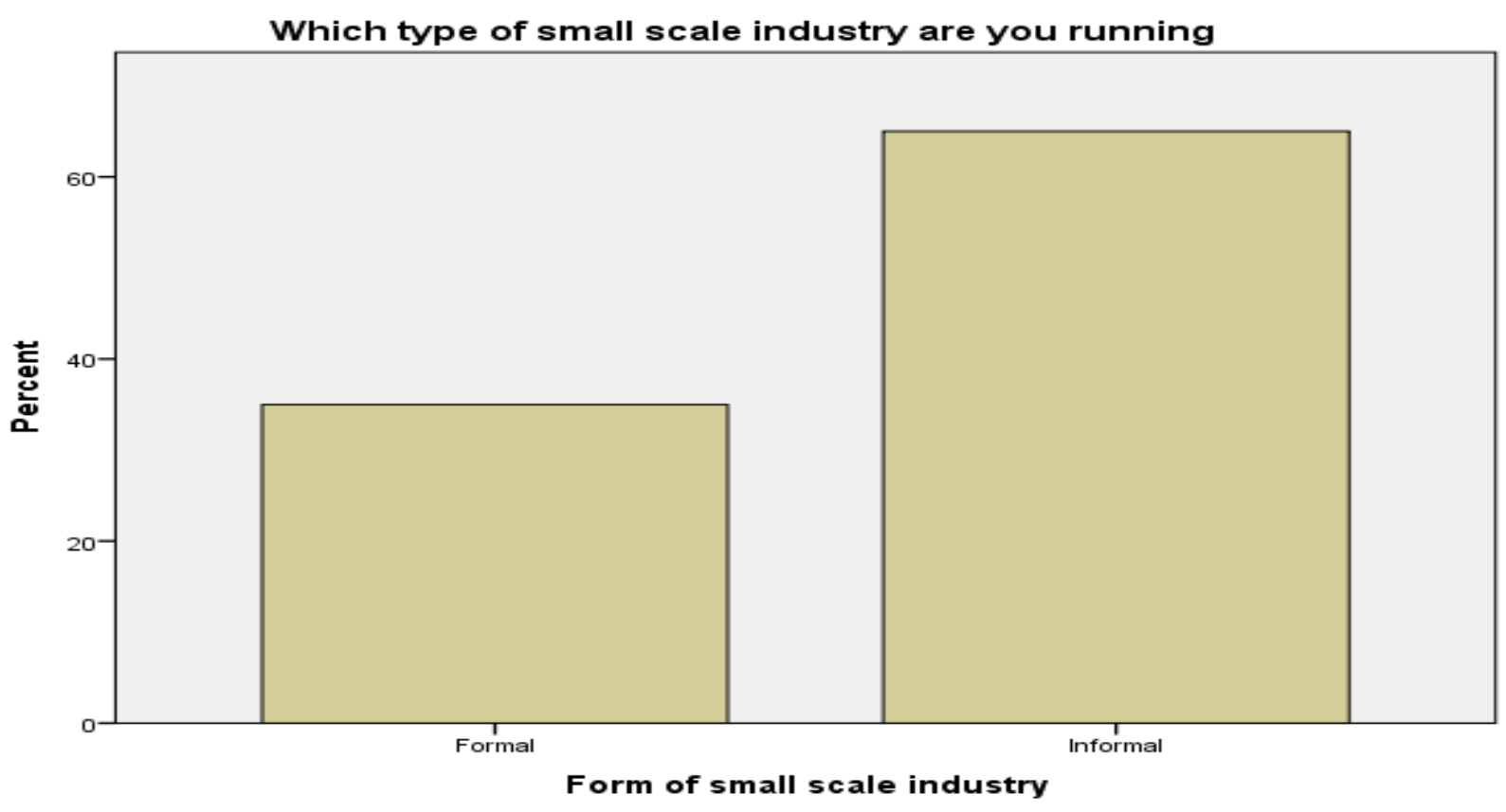

Source: Field Survey (2019).

The chart above revealed that $35.0 \%$ of the respondents represent Small Scale operators who operate a formal SSE business while $65.0 \%$ of the respondents represent Small Scale operators that operate an informal SSE business. This statistics revealed that most of the SSE operators are those who have not registered their businesses with the Corporate Affairs Commission.

\section{Figure 4:}

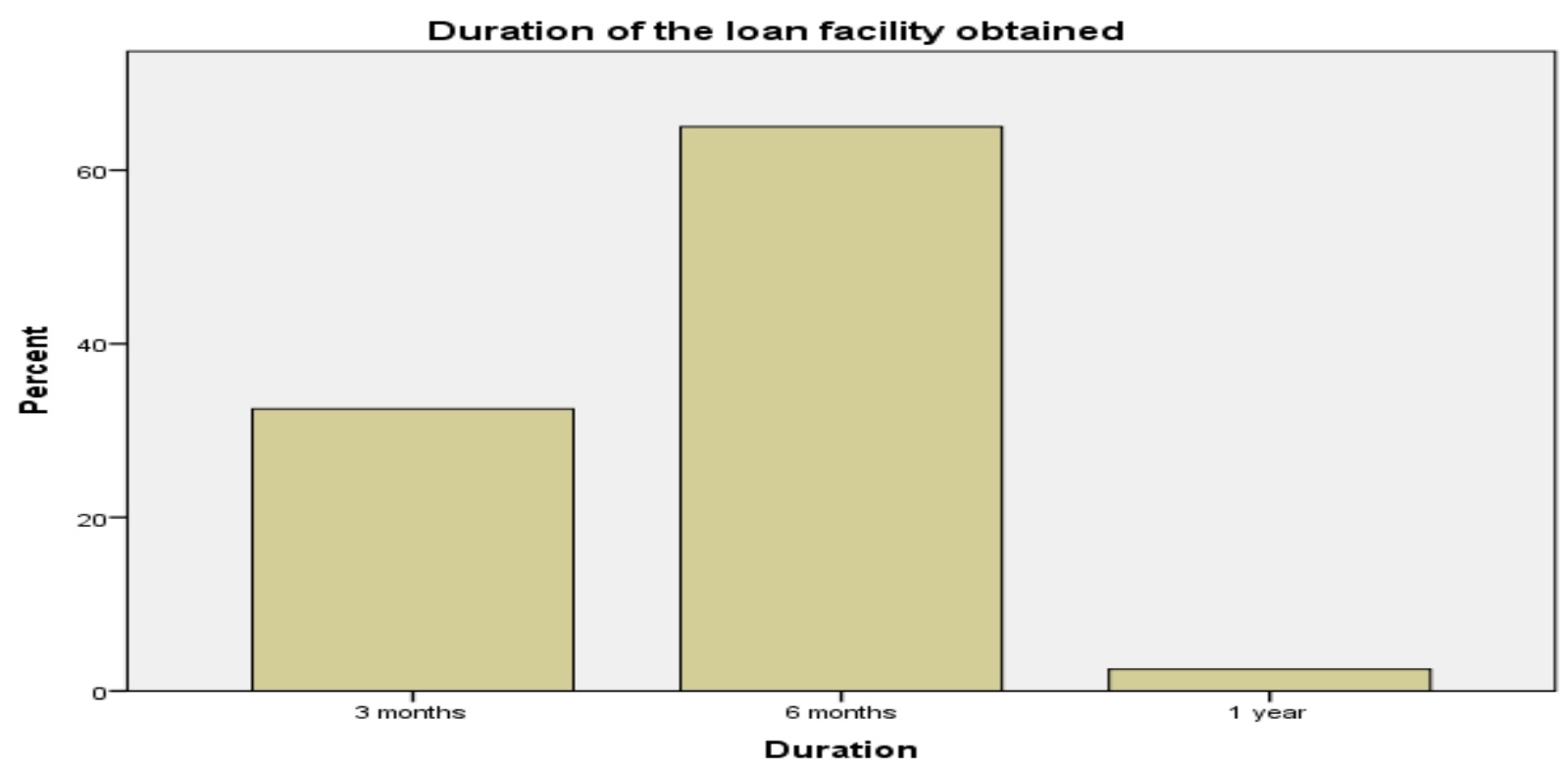

Source: Field Survey (2019). 
The chart above revealed that $32.5 \%$ of the responses are able to obtain loan facilities for a period of 3 months. $65 \%$ of the responses were able to assess loan facilities for a period 6 months. However, $27.5 \%$ of the responses were able to assess loan facilities of a year. This statistics therefore implies that most loan facilities obtained by Small Scale operators have a maturity or repayment date of within 6 months.

\section{I Examining the Effect of Credit Risk Management on Entrepreneurship Development in Nigeria}

The result shown in table I revealed that inadequate policy on fund raising, lack of risk management personnel, lack of credit advisory unit in loan houses, Inability to determine appropriate source of funding are joint predictor of credit risk management on entrepreneurship development in Nigeria which is evidenced in the result where $\mathrm{R}^{2}=0.952$ which indicates that credit risk management have a 95.2\% variance on entrepreneurship development in Nigeria. (F 4, 234) $=1066.468$ far greater than $F$ tabulated; $\mathrm{P}<0.005$ of which the result shows a statistical significance level of 0.000 The individual beta co-efficient, tstatistics and significance of each variable revealed that inadequate policy on fund raising (0.55I; I0.06I; 0.000); Lack of risk management personnel $(0.314 ; 3.972$; 0.000); Lack of credit advisory unit in loan houses $(0.270 ; 2.693$; 0.008); Inability to determine appropriate source of funding $(0.480 ; 6.626$; 0.000) have significant effect on entrepreneurship development; Studies conducted in this area has established high cost and inappropriateness attached to source of finance, Lack of good and standard risk management and monitoring strategy as the major reason for lack of entrepreneurship development in Nigerai. Ango (20I I); Yusuf \& Dansu (20I3); Terungwa (20I2); Alese \& Alimi (20I4); Gakure, Ngugi, Ndwiga \& Waithaka (20I2); this study have further found that as much as source of finance and risk management affects entrepreneurship development, Inadequate policy on fund raising have even more greater effect.

In conclusion, the findings of the study have clearly shown that credit risk management has a significant effect on the development of entrepreneurship in Nigeria. As such, the null hypothesis which states that Credit risk management has no significant impact on entrepreneurship development in Nigeria was rejected.

Table I. Effect of Credit Risk Management on Entrepreneurship Development in Nigeria

\begin{tabular}{lllllc}
\hline S/N & \multicolumn{1}{c}{ ITEMS } & SA & A & D & SD \\
\hline I & $\begin{array}{l}\text { Inadequate policy on fund raising affects entrepreneurship } \\
\text { development. }\end{array}$ & I22 & 84 & 27 & 7 \\
\hline 2 & $\begin{array}{l}\text { Lack of risk management personnel hinders the progress of Small } \\
\text { Scale Enterprises. }\end{array}$ & II4 & 96 & 24 & 6 \\
\hline 3 & $\begin{array}{l}\text { Lack of credit advisory unit in loan houses affects the development } \\
\text { of entrepreneurs. }\end{array}$ & II6 & 77 & 42 & 5 \\
\hline 4 & $\begin{array}{l}\text { Do you agree that the inability of an entrepreneur to determine the } \\
\text { appropriate source of fund to raise hinders the development of } \\
\text { Small Scale Enterprises }\end{array}$ & 99 & I5 & 9 \\
\hline 5 & $\begin{array}{l}\text { Do you agree that lack of credit risk management serves as a } \\
\text { hindrance to entrepreneurship development in Ondo state? }\end{array}$ & 9I & I7 & 8 \\
\hline Source: Descriptive Statistics SPSS 20.0 (20I7) & & & & 8
\end{tabular}

Model Summary

\begin{tabular}{|l|r|r|r|r|}
\hline Model & \multicolumn{1}{|c|}{$\mathrm{R}$} & R Square & \multicolumn{1}{c|}{$\begin{array}{c}\text { Adjusted R } \\
\text { Square }\end{array}$} & $\begin{array}{c}\text { Std. Error of the } \\
\text { Estimate }\end{array}$ \\
\hline $\mathrm{I}$ & $.976^{\mathrm{a}}$ & .952 & .952 & $.166 \mathrm{I} 2$ \\
\hline
\end{tabular}

\begin{tabular}{|c|c|c|c|c|c|c|}
\hline \multicolumn{7}{|c|}{ ANOVA $^{a}$} \\
\hline & & Sum of Squares & Df & Mean Square & $\mathrm{F}$ & Sig. \\
\hline \multirow{3}{*}{ I } & Regression & II7.723 & 4 & 29.431 & I066.468 & $.000^{\mathrm{b}}$ \\
\hline & Residual & 5.878 & 234 & .028 & & \\
\hline & Total & $\mathrm{I} 23.60 \mathrm{I}$ & 238 & & & \\
\hline
\end{tabular}


Coefficients $^{\mathrm{a}}$

\begin{tabular}{|c|c|c|c|c|c|c|}
\hline \multirow[t]{2}{*}{ Mod } & & \multicolumn{2}{|c|}{ Unstandardized Coefficients } & \multirow{2}{*}{$\begin{array}{c}\begin{array}{c}\text { Standardized } \\
\text { Coefficients }\end{array} \\
\text { Beta }\end{array}$} & \multirow[t]{2}{*}{$\mathrm{T}$} & \multirow[t]{2}{*}{ Sig. } \\
\hline & & B & Std. Error & & & \\
\hline \multirow{5}{*}{$\mathrm{I}$} & (Constant) & .045 & .027 & & 1.659 & .099 \\
\hline & $\begin{array}{l}\text { Inadequate policy on fund } \\
\text { raising affects entrepreneurship } \\
\text { development. }\end{array}$ & .526 & .052 & $.55 \mathrm{I}$ & I0.061 & .000 \\
\hline & $\begin{array}{l}\text { Lack of risk management } \\
\text { personnel hinders the progress } \\
\text { of Small Scale Enterprises. }\end{array}$ & -.308 & .077 & $-.3 \mathrm{I} 4$ & -3.972 & .000 \\
\hline & $\begin{array}{l}\text { Lack of credit advisory unit in } \\
\text { loan houses affects the } \\
\text { development of entrepreneurs. }\end{array}$ & $.27 \mathrm{I}$ &. $\mathrm{IOI}$ & .270 & 2.693 & .008 \\
\hline & $\begin{array}{l}\text { Do you agree that the inability } \\
\text { of an entrepreneur to determine } \\
\text { the appropriate source of fund } \\
\text { to raise hinders the } \\
\text { development of Small Scale } \\
\text { Enterprises }\end{array}$ & .459 & .069 & .480 & 6.626 & .000 \\
\hline
\end{tabular}

Source: Field Survey (2019).

\subsection{Determining the Impact of Access to Credit Facilities on Business Expansion}

Analysis of Variance (ANOVA) was used to test for the impact of access to credit facilities on business expansion using SPSS 20.0 version. The individual mean square, F-statistics and the significance was determined to find out the effect of each factor on business expansion.

The result shown in Table 4.2 revealed that low collapse rate, increased rate of employment creation, creation of wealth, ease in opening new outlet and branches, increase in volume of sales are joint indicators of the effect of access to credit facilities on business expansion. This was evidenced in the result which was interpreted using the individual mean square, FStatistics and Significance.

The result obtained clearly shows that low collapse rate (57.473; I238.08; 0.000), increased rate of employment (51.039; 942.687; 0.000); Creation of wealth (39.155; 402.928; 0.000); Ease in opening new outlets and branches (46.825; $645.214 ; 0.000)$; Increase in the volume of sales $(48.840 ; 566.628 ; 0.000)$ are all significantly positively affected by access to credit facilities. This therefore implies that as much as the Small Scale Sector can assess credit facilities, there exists a positive link between the credit facility and business expansion as well as economic growth as large. Studies conducted in this area has established that improvement in the economic size of the Nigerian economy and an increase in the Gross Domestic Product are the contribution of access to credit facilities on business expansion. Alese and Alimi (20I4); Joseph and Nnanyelugo (20I5); this study have further found out that the impact of credit facilities on business expansion can be felt from both the perspective of Economic growth as well as Economic Development.

The findings of the study have therefore, clearly shown that access to credit facilities have a positive significant effect on business expansion. As such, the null hypothesis which states that Access to credit facilities does not have any significant impact on business expansion was rejected.

Table 2. Determine the Impact Of Access to Credit Facilities on Business Expansion

\begin{tabular}{clcccc}
\hline S/N & Questions & SA & A & D & SD \\
\hline I & $\begin{array}{l}\text { Do you agree that SSEs that are able to access credit facilities enjoy } \\
\text { business growth and expansion? }\end{array}$ & 98 & 85 & $4 \mathrm{I}$ & $\mathrm{I}$ \\
\hline 2 & $\begin{array}{l}\text { SSEs that are able to secure loans have a low business collapse rate } \\
3\end{array}$ & $\begin{array}{l}\text { Do you agree that SSEs that are able to gain access to credit } \\
\text { facilities have increased the rate of employment creation }\end{array}$ & 79 & 39 & I7 \\
\hline
\end{tabular}




\begin{tabular}{clcccc}
\hline 4 & $\begin{array}{l}\text { Do you agree that access to loans contribute to the creation of } \\
\text { wealth of SSEs? }\end{array}$ & IOI & 86 & $4 \mathrm{I}$ & I2 \\
\hline 5 & $\begin{array}{l}\text { SSEs that are able to access loans and other credit facilities find it } \\
\text { with ease in opening new outlets and branches. }\end{array}$ & I02 & 89 & 37 & I2 \\
\hline 6 & $\begin{array}{l}\text { The services rendered by MFBs have a positive effect on the } \\
\text { volume of sales of SMEs }\end{array}$ & I04 & $4 \mathrm{I}$ & $\mathrm{I} 4$ \\
\hline
\end{tabular}

Source: Descriptive Statistics SPSS 20.0 (2019)

\begin{tabular}{|c|c|c|c|c|c|c|}
\hline \multicolumn{7}{|c|}{ ANOVA } \\
\hline & & $\begin{array}{l}\text { Sum of } \\
\text { Squares }\end{array}$ & Df & Mean Square & $\mathrm{F}$ & Sig. \\
\hline SSEs that are able to secure & Between Groups & $\mathrm{I} 72.4 \mathrm{I} 8$ & 3 & 57.473 & 1238.080 & .000 \\
\hline loans have a low business & Within Groups & 9.563 & 206 & .046 & & \\
\hline collapse rate & Total & I8I.98I & 209 & & & \\
\hline Do you agree that SSEs that & Between Groups & I53.116 & 3 & 51.039 & 942.687 & .000 \\
\hline $\begin{array}{l}\text { are able to gain access to } \\
\text { credit facilities have }\end{array}$ & Within Groups & II.3I6 & 209 & .054 & & \\
\hline $\begin{array}{l}\text { increased the rate of } \\
\text { employment creation }\end{array}$ & Total & I 64.432 & 212 & & & \\
\hline Do you agree that access to & Between Groups & I I7.465 & 3 & 39.155 & 402.928 & .000 \\
\hline loans contribute to the & Within Groups & 20.310 & 209 & .097 & & \\
\hline creation of wealth of SSEs? & Total & $\mathrm{I} 37.775$ & $2 \mathrm{I} 2$ & & & \\
\hline SSEs that are able to access & Between Groups & $\mathrm{I} 40.475$ & 3 & 46.825 & $645.2 \mathrm{I} 4$ & .000 \\
\hline $\begin{array}{l}\text { loans and other credit } \\
\text { facilities find it with ease in }\end{array}$ & Within Groups & I5.I68 & 209 & .073 & & \\
\hline $\begin{array}{l}\text { opening new outlets and } \\
\text { branches. }\end{array}$ & Total & I 55.643 & 212 & & & \\
\hline The services rendered by & Between Groups & $\mathrm{I} 46.520$ & 3 & 48.840 & 556.628 & .000 \\
\hline MFBs have a positive effect & Within Groups & $\mathrm{I} 7.46 \mathrm{I}$ & 199 & .088 & & \\
\hline $\begin{array}{l}\text { on the volume of sales of } \\
\text { SMEs }\end{array}$ & Total & I63.980 & 202 & & & \\
\hline
\end{tabular}

Source: Field Survey (2019).

\subsection{Identify the Effect of the Constraints Faced By SSEs in Accessing Finance and Managerial Capacity on Entrepreneurship Development}

Regression was used to test the effect of the constraints faced by SSEs in accessing finance and managerial capacity on entrepreneurship development. The result shown in table 3 revealed that lack of enabling environment, lack of effective and appropriate managerial skills are joint predictor of the constraint of accessing finance and managerial capacity on entrepreneurship development which was evidenced in the result where $\mathrm{R}^{2}=0.975$ which indicates that constraints on accessing finance and managerial capacity have a $97.5 \%$ variance on entrepreneurship development in Nigeria. (F 3, 209) $=2695.182$ far greater than F tabulated; $\mathrm{P}<0.005$ of which the result shows a statistical significance level of 0.000 The individual beta coefficient, t-statistics and significance of each variable revealed that lack of enabling environment (0.192; 4.129; 0.000); Lack of effective and appropriate managerial skills $(0.796 ; 22.918 ; 0.000)$; have significant effect on entrepreneurship development; Studies conducted in this area has established difficulty in sourcing for fund; Basic infrastructures; Lack of required skills as the major constraints of entrepreneurship development in Nigeria. Ango (20II); Yusuf and Dansu (2013); Ofili (20I4); this study have further found that lack of effective and appropriate managerial skills have even more greater effect on entrepreneurship development. It was also revealed from the findings that lack of market opportunity $(0.008 ; 0.234 ; 0.815)$ do not have any effect on entrepreneurship development. This could be hinged on the fact that Nigeria as a country is seen as a market filled with various business opportunities.

In conclusion, the findings of the study have clearly shown that constraints faced by SSEs in accessing finance and managerial capacity have a significant effect on entrepreneurship development in Nigeria. As such, the null hypothesis which states that the constraints faced in accessing finance and managerial capacity does not have any significant effect on entrepreneurship development was rejected. 
Table 3. Effect of the Constraints faced By SSEs in Accessing Finance and Managerial Capacity on Entrepreneurship Development

\begin{tabular}{|c|c|c|c|c|c|}
\hline $\mathrm{S} / \mathrm{N}$ & Questions & SA & A & $\mathrm{D}$ & $\mathrm{SD}$ \\
\hline $\bar{I}$ & $\begin{array}{l}\text { Lack of market opportunities can affect entrepreneurship } \\
\text { development. }\end{array}$ & I04 & 82 & 42 & $\mathrm{I} 2$ \\
\hline 2 & $\begin{array}{l}\text { Do you agree that inadequate market information on access to } \\
\text { finance and managerial capacity serves as a constraint to } \\
\text { entrepreneurship development? }\end{array}$ & 90 & 86 & 39 & I5 \\
\hline 3 & $\begin{array}{l}\text { Lack of enabling environment can hinder the effective discharge of } \\
\text { SSEs role in economic development }\end{array}$ & I04 & 84 & 38 & $\mathrm{I} 4$ \\
\hline 4 & $\begin{array}{l}\text { SSEs are affected by the lack of effective and appropriate } \\
\text { managerial skills }\end{array}$ & III & 78 & $4 I$ & $\mathrm{IO}$ \\
\hline 5 & $\begin{array}{l}\text { Do you agree that the challenges faced by SSEs in Nigeria have } \\
\text { effect on the development of entrepreneurs? }\end{array}$ & 109 & $8 \mathrm{I}$ & 39 & II \\
\hline
\end{tabular}

Model Summary

\begin{tabular}{|l|r|r|r|r|}
\hline Model & \multicolumn{1}{|c|}{ R } & R Square & \multicolumn{1}{c|}{$\begin{array}{c}\text { Adjusted R } \\
\text { Square }\end{array}$} & $\begin{array}{c}\text { Std. Error of the } \\
\text { Estimate }\end{array}$ \\
\hline I & $.987^{\mathrm{a}}$ & .975 & .974 &. $\mathrm{I} 2792$ \\
\hline
\end{tabular}

\section{ANOVA $^{2}$}

\begin{tabular}{|rl|r|r|r|r|r|}
\hline Model & & Sum of Squares & Df & Mean Square & \multicolumn{1}{c|}{ F } & Sig. \\
\hline \multirow{2}{*}{ I } & Regression & I32.299 & 3 & 44.100 & 2695.182 & $.000^{\mathrm{b}}$ \\
& Residual & 3.420 & 209 & .016 & & \\
& Total & 135.718 & $2 \mathrm{I} 2$ & & & \\
\hline
\end{tabular}

\section{Coefficients $^{\mathrm{a}}$}

\begin{tabular}{|c|c|c|c|c|c|c|}
\hline \multirow{2}{*}{\multicolumn{2}{|c|}{ Model }} & \multicolumn{2}{|c|}{ Unstandardized Coefficients } & \multirow{2}{*}{$\begin{array}{c}\begin{array}{c}\text { Standardized } \\
\text { Coefficients }\end{array} \\
\text { Beta }\end{array}$} & \multirow[t]{2}{*}{$\mathrm{t}$} & \multirow[t]{2}{*}{ Sig. } \\
\hline & & $\mathrm{B}$ & Std. Error & & & \\
\hline \multirow{4}{*}{ I } & (Constant) & $.0 \mathrm{II}$ & .022 & & .524 & .601 \\
\hline & $\begin{array}{l}\text { Lack of market opportunities } \\
\text { can affect entrepreneurship } \\
\text { development. }\end{array}$ & .008 & .033 & .008 & .234 & .815 \\
\hline & $\begin{array}{l}\text { Lack of enabling environment } \\
\text { can hinder the effective } \\
\text { discharge of SSEs role in } \\
\text { economic development }\end{array}$ & .185 & .045 & .192 & 4.129 & .000 \\
\hline & $\begin{array}{l}\text { SSEs are affected by the lack of } \\
\text { effective and appropriate } \\
\text { managerial skills }\end{array}$ & .798 & .035 & .796 & 22.918 & .000 \\
\hline
\end{tabular}

\section{Conclusions}

SSEs in every economy in the world require access to finance as well as mange the risk involved in facilitating credit facilities for their business to thrive on a sustainable basis. The study has shown that poor credit risk management serves as a drawback in the stride towards achieving improved entrepreneurship development. Results from this study have shown that for Small Scale 
Enterprises to stand as a driving force towards achieving economic growth and development, access to credit facility plays a significant roles as result have clearly shown that access to credit have an enormous significant impact on business expansion. Furthermore, the findings of this study have shown constraints faced by SSEs in accessing Finance and Managerial Capacity have negative significant effect on the rate of entrepreneurship development.

As such, credit and credit risk management among SSEs should be given prior recognition as they have clearly shown that they can serve as bedrock on which SSEs and the nation can build on towards achieving the economic breakthrough.

\section{Recommendations}

From the findings of the study, the following recommendation which can be extracted for policy statement for government and management are made;

The importance of credit risk management to business sustainability and entrepreneurship development cannot be overemphasized. Although, findings have shown that not all small Scale Enterprises can afford to set up a risk management unit due to the informal nature of most SSEs operation. As such, Policy makers, Industrialists and Financial Institutions should ensure that an effective risk management unit is put in place so as to give SSEs operators advisory services as well as enlighten them on the need to consult the risk management unit before determining issues relating to the types of fund to use and how it should be sourced.

Finance is said to be the bedrock of business operations. This means that the role of Government in ensuring that SMEs can be relied upon as a backbone for economic growth and development is vital. As such, policy makers and financial institutions should ensure that means such as favorable interest rates, soft or no collateral backed loans and other mediums suitable to encourage SSEs in obtaining loans externally are devised to ensure that financial services can be easily accessed and relied on by SSEs operators.

Government should ensure that it provide the much needed enabling environment for both SSEs operators to operate. SSEs operators should also ensure that the right hands are placed on desk to manage the affairs of the organization.

\section{References}

Aernold, R. (1998). Round table discussion on recommendations for best practice in financial intermediaries for SMEs, in: Final Report of Expert Meeting on Best Practice in Financing SMEs. United Nations/ECE, Geneva, Switzerland

Agumagu, A.C. (2006). Finance for Industry and Commerce, the Business of Banking, Lectures and Proceedings at the 26th International Banking Summer School, Oxford.

Akabueze, B. (2002). Prospectus on Nigeria SMEs under the Small and Medium Industries Investment Scheme (SMIEIS). Accessed August I4, 2009 from www.nigeriabusinessinfor.com/nigerian-smes2000.htm

Aladekomo, F.O. (2003). The Small and Medium Enterprises (SME) Landscape: Environment, Government Policies, programmes, and Institutional Support, A paper delivered at the two-day workshop on Strategies for Operationalizing Small and Medium Industries Equity Investment Scheme (SMIES) in Nigeria on 23-24 August, 2003, at WEMA Bank Training School, Oba Akran Avenue, Ikeja, Lagos, Nigeria.

Alfred, S.H. (20II). Record Keeping and Accounts as a Tool for Growth of Small Scale Enterprises in Nigeria Economy. Multidisciplinary Joumal of Empirical Research, 9 (I), I10-I20.

Allal, M. (1999). Business Development Services for MSEs in Thailand in MSE Development and Poverty Alleviation in Thailand, Finnega Gerry (ed.), and ILO/UNDP Working paper

Allen, N. \& Udell, G. F. (2002). Small business credit availability and relational lending: the importance of bank organisational structure. The Economic Joumal. II2 (2), 32-53.

Amaeshi, U.F. (2005). Entrepreneurship, Enugu. Publishers Ltd

Amaeshi, U.F (2007). Entrepreneurship as a core Economic Development Strategy for Nigeria; Journal of Business \& Management Studies, I(2). I-9

Anic, V. \& Paus, V. (I998). The Croatian SME study: Best practice in Financing SMEs in SECI and CEI Countries In: Final Report of UN/ECE Expert Meeting on Best practice in Financing SMEs. Geneva

Aruwa, S.A.S. (2004). Financing options for small and medium- scale enterprises in Nigeria, The Nigeria Journal of Accounting and Research, Department of Accounting, Ahmadu Bello University, Zaria. I (2).

Aruwa, S.A.S (2004). Financing options for small and medium-scale enterprises in Nigeria, The Nigerian Journal of Accounting and Research, Department of Accounting, Ahmadu Bello University, Zaria. I(2), June.

Azende, T. (2012). Risk Management and Insurance of Small and Medium Scale Enterprises (SMEs) in Nigeria. International Journal of Finance and Accounting, I(I), 8-I7.

Azende, T. (2012). Risk Management and Insurance of Small and Medium Scale Enterprises (SMEs) in Nigeria. International Journal of Finance and Accounting, I(I), 8-17.

Baumol, W. J. (1993). Formal Entrepreneurship Theory in Economic: Existence and Bonds._Journal of Business Venturing 8, I97-2I0 
Beck, T. Demirgue-Kunt, L. \& Levine, K. (2006). SMEs, growth, and poverty. National Bureau of Economic Research Working paper II224, Cambridge

Beck, T T. \&Demirguc-Kunt, L. (2006). Small and medium-sized enterprises: Access to finance as a growth constraint. Journal of Banking and Finance. 293I-2943.

Blanchflower,T.\& David, P. \& Andrew O. (1998). What Makes an Entrepreneur, Journal of Labor Economics, I6(I) 26-60

Central Bank of Nigeria (2008). Statistical Bulletin. Central Bank of Nigeria Publication. I-420.

Chidi, C. \& Shadare, O. (20I I). Managing human capital development in small and medium sized enterprises for sustainable national development in Nigeria. International Joumal of Management and Information Systems, I5(2), 95-I04

Colquitt, J. (2007). Credit Risk Management. How to Avoid Lending Disasters \& Maximize Earnings. 3rd Edition. McGraw-Hill. USA.

Crouhy, M.; Galai, D. \& Mark, T. (2006). The Essentials of Risk Management. McGraw-Hill. USA

Drucker Peter F. (1985). Innovation and Entrepreneurship. Heinemann, London, 20.

Ekpenyong, D.B.E. \& Nyong, M. O. (1992). Small and medium-scale enterprises development In Nigeria. Seminar Paper on Economic Policy Research for Policy Design and Management in Nigeria. NCEMA/AEPC, Nigeria, April 24-25.

Essien, O. E. (200I). The Role of Development Finance Institutions in the Financing of Small Scale Industries. CBN Bullion. 25(3).

Evans, P. David S., and Boyan, J. (1989). An estimated model of entrepreneurial choice under liquidity constraints, Journal of Political Economy 97, 808-827

Fabunmi, B .C. (2004). Small and Medium Scale Industries Nigeria: Problems, Prospects and Management Techniques; 2nd Ed. Akure, JBS Printing and Publishing

Golis, C. (1998). Enterprise and Venture Capital: A Business Builder and Investment Handbook, 3rd edition, Australia: Allen and Urwin

Honourary Presidential Advisory Council on Investment in Nigeria (HPACI, 2002). Sectoral Profiles on Small and Medium Scale Enterprises. I(2), May.

Hurst, R. E. \& Annamaria,L. (2004). Liquidity Constraints, Household Wealth, and Entrepreneurship. Journal of Political Economy, II2(2), 319-47I

Ilpo, A., Passi, M. \& Mikko, K. (2004). Intergenerational Transmission of Poverty in Finland in the I990s. University of Turkey, Department of social Policy Series C: I3.

Inang, E.E. \& Ukpong, G.E. (I992). A review of small-scale enterprises credit delivery strategies in Nigeria. Economic and Financial Review. CBN, 30(4), December.

Irwin, F. (1966). The Propensity to save in India, Dr. P. S. Loknathan $72^{\text {nd }}$ Birthday Commemoration Volume, VoveedCo. Bombay. 163-170

John, A. \& Olorunfemi Y. \& ALIMI, B. (201 I). International Journal of Social Sciences and Entrepreneurship I, Issue I I, 2014 http://www.ijsse.org ISSN 2307-6305

Kairu, P K. (2009). Credit Management Second Edition, Focus Publishers Ltd Nairobi

Kauffman, C. (2005). Financing SMEs in Africa. Policy Insights, A publication of the OECD development centre.

King, R. \& Levine, R. (1993). Finance, Entrepreneurship and Growth: Theory and evidence. Journal of Monetary Economics. 32(I), 513-542

Kpelai, S. T. (2009). Entrepreneurship Development in Nigeria. Makurdi: Aboki Publishers.

Luy, D. D. (2010). Evaluation of Credit Risk Management Policies and Practices in a Vietnamese Joint-Stock Commercial Banks Transaction Office. Business Economics and Tourism.

Mainoma, M.A. (2005). The nexus between risk and investment decision: Experiences from Nigerian investment climate, Nigeria Journal of Accounting Research, Department of Accounting, ABU, Zaria. I(3) Dec., 2005. 64

Mambula, C. (2002). Perceptions of SME growth constraints in Nigeria. Journal of Small Business Management, 40 (I), 58 65.

Mambula, T. \& Charles, A. (2002). Perception of SME Growth Constraints in Nigeria. Journal of Small Business Management, 40(I), 58-65.

Margrabe, K. (2007). The incidence of secured debt: evidence from the small business community, Journal of Financial and Quantitative Analysis, 24(I) 379-94.

Mason, G. \& Roger B. (1998). A capital adequacy framework for Islamic banks: the need to reconcile depositors' risk aversion with managers' risk taking, Applied Financial Economics, I4(4), 429-4I.

Morris, J. (200I). Risk Diversification in the Credit Portfolio: An Overview of Small and Medium-Scale Enterprises Financing and Economic Growth in Nigeria: Error Correction Mechanism

Murthy, N. (1989). Entrepreneurship in Small Towns, In Samuddin (ed) Entrepreneurship Development in India, Mittal Publication, Delhi 4. 
Mwirigi P. \& Kwagara, A. (2006). An Assessment of Credit Risk Management techniques adopted by micro finance institutions in Kenya.Unpublished MBA research project, University of Nairobi.

Njoku, S. (2007). The capital flight challenge for the Nigerian industrial sector. Real Sector Digest, Business Day, August I5.

Ohanga, M. (2005). Bank lending practices to small and medium sized enterprises. Retrieved NovemberI I, 2009 from http.

Ohanga, M. (2005). Bank lending practices to small and medium sized enterprises. Retrieved NovemberI I, 2009 from http

Ojo, A.T. (2004). Using SME's to Achieve Millennium Development Goals: Lessons of Experience from other Countries, Paper Presented at the 2004 SMED's SME Stakeholders' Conference, Kaduna December 2004.

Ojo, A.T. (1984). Banking In Nigeria, London: Graham Burn

Onugu, B. (2005). Tackling obstacles to accessing SMEEIS fund. Nigeria Tribune, Thursday, 2 March.

Owualah, S. I. (I999) Entrepreneurship in Small Business Firms, Lagos; G. Mag Investment Limited

Plourd, K. (2009). Rethinking risk. CFO. January: 66-69. Pretorius M, Shaw G (2004). Business plans in bank decisionmaking when financing new ventures in South Africa. South Afr. J. Econ. Manage. Sci., 7(2): 22I -24I. [Online].

Sanusi, J. (2004). Research study presentation at the National summit on revamping small and medium industries, This Day. I0, (3243), 25.

Say, J. B. (1994). A Treatise of Political Economy or the Production, Distribution and Consumption of Wealth Entrepreneurs in India, in Samiuddin (ed) Entrepreneurship in Development in India. Mittal Publication Delhi 39

Schneider-Barthold, W. (2002). Africa's aborted industrialisation: Modernisation strategies impede organic industrial growth. D+C Development and Cooperation. I(I), I5-I7, Deutsche Stiftung Fur Internationale Entwicklung (DSE), Germany.

Schumpeter, J. A. (1934). The Theory of Economic Development. HarvardUniversity Press. Cambridge. M. A.

Schumpeter, J. A. (1959). The Theory of Economic Development. HarvardUniversity Press, Cambridge, Massachusetts.

Schumpeter, Joseph A. (195I). Economic Theory and Entrepreneurial History, in R. V. Clemence, (ed). Essays on Economic Topics of Joseph Schumpeter. Port Washington, NY: Kennikat Press

Somoye, R.O.C. (20I I). The Role of Financial Intermediation in Entrepreneurship Financing in Nigeria - Thesis in partial fulfilment of the Business School, Faculty of Business and Creative Industries, University of the West of Scotland, Scotland United Kingdom, for the award of Doctor of Philosophy (Ph.D.)

Storey, D. J. (2003). Entrepreneurship, Small and Medium Sized Enterprises and Public Policies, In Z. J. Acs\& D. B. Audretsch (eds). Handbook of Entrepreneurship Research (473 - 5II). Heidelberg, Germany: Springer Science + Business Media.

Sule, E.I.K. (1986). Small scale industries in Nigeria: Concepts, appraisal of government policies and suggested solutions to identified problems, CBN Economic and Financial Review, 24(4).

Tandon, B. C. (1973). Environment and Entrepreneur, Chug Publication, Allahabad. 60

Torres-Reyna, O. (2007). Panel data analysis: Fixed and random effects using STATA, Princeton University. Available from http://dss.princeton

Vaughan, E. J. (1997). Risk Management, New York: wiley

Vision 2020 (2009). National Technical Working Group on Small and Medium Enterprises (SMEs). Abuja: Vision 2020, Nigeria

Williams, O. \& Bultrick, J. (1969). Economic Development - Change and Entrepreneur, Cambridge University Press. $265-$ 285

World Bank (2010). World Bank group support for small business. Washington DC:

Yushau I. A. (2009). Lecturer Department of Business Administration Faculty of Social and Management Sciences Kaduna State University ACRN Journal of Entrepreneurship Perspectives 2 (2), 2I-45, Oct. 2013 ISSN 2224-9729

\section{Copyrights}

Copyright for this article is retained by the author(s), with first publication rights granted to the journal. This is an open-access article distributed under the terms and conditions of the Creative Commons Attribution license (http://creativecommons.org/licenses/by/4.0/). 